Article

\title{
Discovery, Pharmacological Characterisation and NMR Structure of the Novel $\mu$-Conotoxin SxIIIC, a Potent and Irreversible Nav Channel Inhibitor
}

\author{
Kirsten L. McMahon ${ }^{1}{ }^{\circledR}$, Hue N.T. Tran ${ }^{1}{ }^{\mathbb{D}}$, Jennifer R. Deuis ${ }^{1}$, Richard J. Lewis ${ }^{1}{ }^{\circledR}$, \\ Irina Vetter $1,2, * \mathbb{D}$ and Christina I. Schroeder $1,3, * \mathbb{D}$ \\ 1 Institute for Molecular Bioscience, The University of Queensland, Brisbane, QLD 4072, Australia; \\ k.mcmahon@uq.edu.au (K.L.M.); hue.tran56@uq.net.au (H.N.T.T.); j.deuis@uq.edu.au (J.R.D.); \\ r.lewis@uq.edu.au (R.J.L.) \\ 2 The School of Pharmacy, The University of Queensland, Woolloongabba, QLD 4102, Australia \\ 3 National Cancer Institute, National Institutes of Health, Frederick, MD 21702, USA \\ * Correspondence: i.vetter@uq.edu.au (I.V.); christina.schroeder@nih.gov (C.I.S.)
}

Received: 20 August 2020; Accepted: 29 September 2020; Published: 2 October 2020

\begin{abstract}
Voltage-gated sodium $\left(\mathrm{Na}_{\mathrm{V}}\right)$ channel subtypes, including $\mathrm{Na}_{\mathrm{V}} 1.7$, are promising targets for the treatment of neurological diseases, such as chronic pain. Cone snail-derived $\mu$-conotoxins are small, potent $\mathrm{Na}_{\mathrm{V}}$ channel inhibitors which represent potential drug leads. Of the $22 \mu$-conotoxins characterised so far, only a small number, including KIIIA and CnIIIC, have shown inhibition against human $\mathrm{Na}_{\mathrm{V}}$ 1.7. We have recently identified a novel $\mu$-conotoxin, SxIIIC, from Conus striolatus. Here we present the isolation of native peptide, chemical synthesis, characterisation of human $\mathrm{Na}_{\mathrm{V}}$ channel activity by whole-cell patch-clamp electrophysiology and analysis of the NMR solution structure. SxIIIC displays a unique $\mathrm{Na}_{\mathrm{V}}$ channel selectivity profile $(1.4>1.3>1.1 \approx 1.6 \approx 1.7>1.2>>1.5 \approx 1.8)$ when compared to other $\mu$-conotoxins and represents one of the most potent human $\mathrm{Na}_{\mathrm{V}} 1.7$ putative pore blockers ( $\mathrm{IC}_{50} 152.2 \pm 21.8 \mathrm{nM}$ ) to date. NMR analysis reveals the structure of SxIIIC includes the characteristic $\alpha$-helix seen in other $\mu$-conotoxins. Future investigations into structure-activity relationships of SxIIIC are expected to provide insights into residues important for $\mathrm{Na}_{\mathrm{V}}$ channel pore blocker selectivity and subsequently important for chronic pain drug development.
\end{abstract}

Keywords: chronic pain; $\mu$-conotoxin; Nav channels; pore blocker; whole-cell patch-clamp electrophysiology; NMR

\section{Introduction}

Voltage-gated sodium $\left(\mathrm{Na}_{\mathrm{V}}\right)$ channels are highly conserved pore-forming proteins permeable to sodium ions and are important for the initiation and propagation of action potentials [1,2]. Nine different subtypes are expressed in humans $\left(\mathrm{Na}_{V} 1.1-1.9\right)$ and are encoded by the $S C N x A$ genes $(\mathrm{x}=1-5,8-11)[3]$. Genetic mutations in human $\mathrm{Na}_{\mathrm{V}}$ channels give rise to a number of neurological disorders, for example, epilepsy $\left(\mathrm{Na}_{\mathrm{V}} 1.1\right)$, myotonia $\left(\mathrm{Na}_{\mathrm{V}} 1.4\right)$ and cardiac arrhythmia $\left(\mathrm{Na}_{\mathrm{V}} 1.5\right)$ [4-6]. Moreover, patients with loss of function mutations in $\mathrm{Na}_{\mathrm{V}} 1.7$ present with congenital insensitivity to pain and aside from anosmia (loss of smell) have no serious physiological deficits, highlighting the potential of $\mathrm{Na}_{\mathrm{V}} 1.7$ as a drug target for pain therapeutics [7]. Despite compelling genetic evidence and studies implicating several additional subtypes, including $\mathrm{Na}_{V} 1.1,1.3,1.6,1.8$, and 1.9, as potential targets for pain therapies [8], the clinical utility of $\mathrm{Na}_{\mathrm{V}}$ channel inhibitors has had limited success due to high sequence homology between $\mathrm{Na}_{V}$ channel subtypes, particularly within the pore domain [9], as off-target $\mathrm{Na}_{\mathrm{V}}$ inhibition could lead to undesired side-effects. Therefore, a thorough understanding of subtype selectivity is essential for exploiting $\mathrm{Na}_{V}$ channel inhibitors as therapeutics. Toxins from 
venomous creatures, such as snakes, spiders, and cone snails, provide excellent pharmacological tools to study $\mathrm{Na}_{\mathrm{V}}$ channels $[10,11]$.

The venom of predatory marine cone snails represents a complex source of disulfide-rich bioactive peptides that modulate ion channels, called conotoxins [12]. One of the most numerous and best-characterised conotoxin classes are the $\mu$-conotoxins, which have a distinctive type III cysteine framework (CC-C-C-CC). They are potent and selective $\mathrm{Na}_{\mathrm{V}}$ channel inhibitors and $\mu$-conotoxin research has led to many advances in the understanding of $\mathrm{Na}_{V}$ channel function. In 2001, Li et al. established the clockwise arrangement of the four domains of $\mathrm{Na}_{\mathrm{V}}$ channels using $\mu$-conotoxin GIIIA as a probe [13] and more recently, the structure of human $\mathrm{Na}_{\mathrm{V}} 1.2$ bound to $\mu$-conotoxin KIIIA was solved by cryogenic electron microscopy (cryo-EM), confirming for the first time interactions between $\mu$-conotoxins and the $\mathrm{Na}_{\mathrm{V}}$ channel pore [14]. These recent developments have reinvigorated efforts to exploit $\mu$-conotoxins as drug leads.

$\mu$-Conotoxins represent favourable drug leads due to two key characteristics. First, they are rich in cysteines which form disulfide bonds to afford structural integrity and secondly, their small molecular size (typically 16-26 residues) presents an advantage over larger biologics as they are easily synthesised and amenable to chemical modifications to improve pharmacological traits [15]. Conversely, they present as favourable molecules over similarly acting small molecule $\mathrm{Na}_{\mathrm{V}}$ inhibitors including anesthetics [16], as the increased surface area provides greater contacts with the $\mathrm{Na}_{\mathrm{V}}$ channel pore, which can result in an increased subtype selectivity. To date, $22 \mu$-conotoxins have been described from 13 different Conus species [17]. $\mu$-Conotoxins typically show a preference for $\mathrm{Na}_{V} 1.2$ and $\mathrm{Na}_{V} 1.4$ when evaluated in rat homologues, with the exception of BuIIIB, which shows a preference for $\mathrm{Na}_{\mathrm{V}} 1.3$ [18]. To date only a small number of $\mu$-conotoxins have been found to inhibit human (h)Na 1.7 , including KIIIA (IC $50147 \mathrm{~nm}$ ) [19] and CnIIIC (IC $50485 \pm 94 \mathrm{nM}$ ) [20]. One species receiving relatively little attention is the piscivorous (fish-hunting) Conus striolatus. Until recently only four peptide inhibitors (Sx11.2, Sx4.1, and $\mu$-conotoxins SxIIIA, and SxIIIB) were reported from this species, with SxIIIA potently inhibiting $\mathrm{Na}_{\mathrm{V}} 1.4\left(\mathrm{IC}_{50} 7 \mathrm{nM}\right)$, but not $\mathrm{Na}_{\mathrm{V}} 1.7$ [21]. The activity of the remaining peptides has not been assessed to date.

In the current study, we present the discovery of a novel $\mu$-conotoxin from C. striolatus, named SxIIIC. We have characterised its pharmacological activity as a $\mathrm{Na}_{\mathrm{V}}$ channel inhibitor and evaluated the NMR solution structure. Our research discovered that SxIIIC displays a unique $\mathrm{Na}_{\mathrm{V}}$ channel subtype selectivity profile when compared to other highly-homologous $\mu$-conotoxins. Interestingly, at the therapeutically relevant subtype $\mathrm{Na}_{V} 1.7$, SxIIIC displays nanomolar potency and near irreversible inhibition. To date, SxIIIC represents one of the most potent $\mu$-conotoxin putative pore blocker inhibitors of $\mathrm{hNa}_{\mathrm{V}}$ 1.7. Structural differences between SxIIIC and other $\mu$-conotoxins may provide insight into residues driving potent $\mathrm{Na}_{\mathrm{V}}$ channel inhibition. Future investigation of structure-activity relationships of these pore blockers may open avenues for the successful development of therapeutic $\mathrm{Na}_{\mathrm{V}}$ channel inhibitors.

\section{Experimental Section}

\subsection{Chemicals}

All chemicals were purchased from Sigma Aldrich (Sigma Aldrich, St. Louis, MO, USA) and amino acids were purchased from Chem-Impex International (Chem-Impex International, Inc., Wood Dale, IL, USA) unless otherwise stated.

\subsection{Activity-Guided Isolation of SxIIIC}

Inhibition of $\mathrm{Na}_{\mathrm{V}}$-mediated responses by crude and fractionated venom from C. striolatus was assessed using a FLIPR ${ }^{\text {TETRA }}$ (Molecular Devices, Sunnyvale, CA, USA) high-throughput assay, as previously described [22]. In brief, SH-SY5Y neuroblastoma cells were plated at a density of 120,000 cells/well on 96-well black-walled imaging plates (Corning Inc., Corning, NY, USA) in growth 
medium (RPMI medium: 15\% fetal bovine serum and $1 \mathrm{mM} \mathrm{L}$-glutamine) and cultured for $48 \mathrm{~h}$. Cells were loaded with Calcium 4 No-wash dye (Molecular Devices) diluted in physiological salt solution (PSS; composition (in mM) $140 \mathrm{NaCl}, 11.5$ glucose, $5.9 \mathrm{KCl}, 1.4 \mathrm{MgCl}_{2}, 1.2 \mathrm{NaH}_{2} \mathrm{PO}_{4}, 5 \mathrm{NaHCO}_{3}$, $1.8 \mathrm{CaCl}_{2}$, and $10 \mathrm{HEPES}$ ) by replacing growth medium with dye solution and incubating at $37^{\circ} \mathrm{C}$ for $30 \mathrm{~min}$. Fluorescence responses to the addition of crude venom or venom fractions were recorded every second for $300 \mathrm{~s}$ (excitation, 470-495 nm; emission, 515-575 nm) and responses to the addition of veratridine $(50 \mu \mathrm{M})$ were recorded at $1 \mathrm{~s}$ intervals for a further $300 \mathrm{~s}$.

Crude venom was isolated from one specimen of $C$. striolatus by stripping the venom duct contents. The crude venom was dissolved in $30 \%$ acetonitrile $/ 0.1 \%$ formic acid, vortexed, and centrifuged at $10,000 \times g$ for $5 \mathrm{~min}$ to remove insoluble components. Crude venom $(200 \mu \mathrm{g})$ was fractionated into $45 \times 0.7 \mathrm{~mL}$ fractions (1 per min) using a Vydac, $5 \mu \mathrm{m} \mathrm{C18} \mathrm{218TP,} 250 \times 4.6 \mathrm{~mm}$ column (Grace Davison Discovery Sciences, Columbia, MD, USA) eluted at a flow rate of $0.7 \mathrm{~mL} / \mathrm{min}$ with $5-45 \%$ solvent $\mathrm{B}$ over $45 \mathrm{~min}$ (solvent $\mathrm{A}$, water $\left(\mathrm{H}_{2} \mathrm{O}\right) / 0.1 \%$ formic acid; solvent $\mathrm{B}$, $90 \%$ acetonitrile $/ 0.1 \%$ formic acid), with detection at $214 \mathrm{~nm}$. Activity-guided fractionation was performed using the FLIPR ${ }^{\text {Tetra }}$ high-throughput $\mathrm{Na}_{\mathrm{V}}$ assay described above. Further purification was carried out by size-exclusion chromatography (Superdex Peptide, HR 10/30; Amersham Biosciences, Little Chalfont, UK) using elution with $30 \%$ acetonitrile, $0.1 \%$ formic acid, aqueous at a flow rate of $0.5 \mathrm{~mL} / \mathrm{min}$, with detection at $214 \mathrm{~nm}$. The resulting purified fraction was then analysed on a MALDI-TOF mass spectrometer (4700 Proteomics Analyzer; Applied Biosystems, Mulgrave, VIC, Australia) using $\alpha$-cyano-4-hydroxycinnamic acid $(5 \mathrm{mg} / \mathrm{mL})$ as the matrix.

\subsection{Peptide Sequencing}

The purified peptide was sequenced using Edman degradation at the Australian Proteome Research Facility. Briefly, the peptide was dissolved in $4 \mathrm{M}$ urea in $50 \mathrm{mM}$ ammonium bicarbonate and reduced with $100 \mathrm{nM}$ dithiothreitol at $56^{\circ} \mathrm{C}$ for $1 \mathrm{~h}$ under argon. Subsequently, the sample was alkylated using $220 \mathrm{nM}$ acrylamide for $0.5 \mathrm{~h}$ in the dark. The reaction was quenched by addition of excess dithiothreitol. Following desalting by reversed-phase high-performance liquid chromatography (RP-HPLC), the collected fraction was loaded onto pre-cycled bioprene discs and subjected to 35 cycles of Edman N-terminal sequencing using an Applied Biosystems 494 Procise Protein Sequencing System.

\subsection{Peptide Synthesis}

Synthetic SxIIIC (RGCCNGRGGCSSRWCRDHARCC*) was assembled by solid-phase peptide synthesis on a Liberty Prime automatic synthesiser (CEM, Matthews, NC, USA), on rink amide-AM resin $(0.139 \mathrm{mmol} / \mathrm{g})$ at a $0.1 \mathrm{mmol}$ scale to produce C-terminal amidated peptide $\left(^{*}\right)$ using 9-fluorenylmethoxycarbonyl (Fmoc) methodology. Side-chain protecting groups used were $\operatorname{Arg}(\mathrm{Pbf}), \operatorname{Asn}(\operatorname{Trt}), \mathrm{Cys}(\operatorname{Trt}), \operatorname{His}(\operatorname{Trt}), \operatorname{Ser}(\mathrm{tBu})$, and $\operatorname{Trp}(\mathrm{Boc})$. The peptide was cleaved from resin and side chains simultaneously removed following a $2 \mathrm{~h}$ incubation with $92.5 \%$ trifluoroacetic acid (TFA) $/ 2.5 \%$ anisole $/ 2.5 \%$ triisopropylsilane (TIPS) $/ 2.5 \% \mathrm{H}_{2} \mathrm{O}$. Excess TFA was evaporated by $\mathrm{N}_{2}$ flow and reaction precipitated with ice-cold diethyl ether. Precipitant was collected via gravity filtration on a $20 \mu \mathrm{M}$ frit (Phenomenix, Torrance, CA, USA) and crude peptide dissolved in $50 \%$ solvent $\mathrm{B}$ and lyophilised. Linear SxIIIC was dissolved in $<2 \%$ solvent B and loaded onto a Gemini, $5 \mu \mathrm{m}$ C18 $110 \AA$, $250 \times 21.2 \mathrm{~mm}$ column (Phenomenex, Torrance, CA, USA). Following column equilibration (0-5\% solvent B over $5 \mathrm{~min}$ ), synthetic SxIIIC was purified by RP-HPLC using a linear gradient between $5-25 \%$ over $40 \mathrm{~min}$ at $8 \mathrm{~mL} / \mathrm{min}$. Fractions containing the desired product, identified by electrospray mass spectrometry (ESI-MS), were pooled, lyophilised, and stored at $-20^{\circ} \mathrm{C}$.

KIIIA (CCNCSSKWCRDHSRCC*) with disulfide connectivity Cys1/Cys15, Cys2/Cys9, and Cys4/Cys16 was synthesised as previously described [23]. Briefly, peptide was assembled on Liberty Prime automatic synthesiser (CEM, Matthews, NC, USA) using rink amide-AM resin. Peptide was cleaved from solid support and side chains simultaneously deprotection in $92.5 \% \mathrm{TFA} / 2.5 \%$ TIPS/2.5\% $\mathrm{H}_{2} \mathrm{O} / 2.5 \%$ 3,6-dioxa-1,8-octanedithiol (DODT) for $2 \mathrm{~h}$ at room temperature. Excess TFA was 
evaporated by $\mathrm{N}_{2}$ flow, followed by peptide precipitation in ice-cold diethyl ether and centrifugation. Peptide was redissolved in 50\% solvent B and lyophilised.

\subsection{Oxidation}

Reduced SxIIIC peptide $(0.05 \mathrm{mg} / \mathrm{mL})$ was oxidised at room temperature for $1 \mathrm{~h}$ in $0.1 \mathrm{M}$ Tris- $\mathrm{HCl}$ pH 7.5, $0.1 \mathrm{mM}$ ethylenediaminetetraacetic acid (EDTA), $1 \mathrm{mM}$ glutathione oxidised, and $1 \mathrm{mM}$ glutathione reduced. The reaction was quenched by adding formic acid to a final concentration of $5 \%$. The final SxIIIC product was purified by RP-HPLC on a Gemini, $5 \mu \mathrm{m} \mathrm{C18} 110 \AA, 250 \times 10 \mathrm{~mm}$ column (Phenomenex, Torrance, CA, USA) using a linear gradient between $0-20 \%$ over $40 \mathrm{~min}$ at $3 \mathrm{~mL} / \mathrm{min}$. Fractions containing the desired product eluted at $10 \%$ solvent B and were pooled, lyophilised, and stored at $-20^{\circ} \mathrm{C}$.

Reduced KIIIA peptide $(0.3 \mathrm{mg} / \mathrm{mL})$ was oxidised at room temperature for $24 \mathrm{~h}$ in $0.1 \mathrm{M} \mathrm{NH}_{4} \mathrm{HCO}_{3}$ $\mathrm{pH}$ 8.0, $0.81 \mathrm{mM}$ glutathione oxidised, and $0.81 \mathrm{mM}$ glutathione reduced. The KIIIA reaction was quenched with $1 \%$ TFA. The final KIIIA product was purified, as previously described [23].

\subsection{Whole-Cell Patch-Clamp Electrophysiology}

Automated whole-cell patch-clamp recordings were performed with a QPatch-16 automated electrophysiology platform (Sophion Bioscience, Ballerup, Denmark) using single hole (QPlate 16 with a standard resistance of $2 \pm 0.4 \mathrm{M} \Omega$ ) or multi-hole (QPlate 16X with a standard resistance $0.2 \pm 0.04 \mathrm{M} \Omega-\mathrm{Na}_{\mathrm{V}} 1.8$ only) planar chips on HEK293 cells heterologously expressing $\mathrm{hNa} \mathrm{a}_{\mathrm{V}} 1.1-1.7 / \beta 1$ (SB Drug Discovery, Glasgow, UK) or $\mathrm{CHO}$ cells heterologously expressing $\mathrm{hNa} \mathrm{V}_{\mathrm{V}} 1.8 / \beta 3$ in a tetracycline-inducible system (ChanTest, Cleveland, OH, USA). Recordings were acquired at $25 \mathrm{kHz}$ and filtered with a Bessel filter at $8 \mathrm{kHz}$, and the linear leak was corrected by $\mathrm{P} / 4$ subtraction. Recordings were excluded from analysis if series resistance $>10 \mathrm{M} \Omega$.

Cells were maintained in Minimum Essential Medium Eagle (M5650) supplemented with 10\% v/v fetal bovine serum, $2 \mathrm{mM}$ L-glutamine, and the selection antibiotics geneticin, blasticidin and zeocin as recommended by the manufacturer. Cells were incubated at $37^{\circ} \mathrm{C}$ with $5 \% \mathrm{CO}_{2}$ and split every 3-4 days when reaching 70-80\% confluency using the dissociation reagent TrypLE Express (Thermo Fisher Scientific, Scoresby, VIC, Australia). Cells were passaged $48 \mathrm{~h}$ prior to patch-clamp assay in a $\mathrm{T}-175$ flask and cultured at $37^{\circ} \mathrm{C}$. Expression of $\mathrm{hNa} \mathrm{V}_{\mathrm{V}} 1.8$ was induced by the addition of tetracycline $(1 \mu \mathrm{g} / \mathrm{mL})$ for $48 \mathrm{~h}$ prior to assays. Cells were harvested at $80 \%$ confluence and dissociated with TrypLE Express and resuspended in Ham's F-12 medium (Gibco) supplemented with 25 mM HEPES (Sigma Aldrich, St. Louis, MI, USA), $100 \mathrm{U} / \mathrm{mL}$ Penicillin-Streptomycin (Gibco) and $40 \mu \mathrm{g} / \mathrm{mL}$ trypsin inhibitor from Glycine max (soybean) (Sigma Aldrich), and allowed to recover with stirring for $30 \mathrm{~min}$.

The extracellular solution consisted of (in $\mathrm{mM}$ ) $145 \mathrm{NaCl}, 4 \mathrm{KCl}, 2 \mathrm{CaCl}_{2}, 1 \mathrm{MgCl}_{2}, 10 \mathrm{HEPES}$, and 10 glucose, $\mathrm{pH}$ to 7.4 with $\mathrm{NaOH}$ (adjusted to $305 \mathrm{mOsm} / \mathrm{L}$ with sucrose). The intracellular solution consisted of (in mM) $140 \mathrm{CsF}, 1$ EGTA, $5 \mathrm{CsOH}, 10$ HEPES, and $10 \mathrm{NaCl}$, pH to 7.3 with CsOH (adjusted to $320 \mathrm{mOsm} / \mathrm{L}$ with sucrose). SxIIIC was diluted in extracellular solution with $0.1 \%$ bovine serum albumin. $\mathrm{Na}_{\mathrm{V}} 1.1-1.7$ currents were elicited by a $50 \mathrm{~ms}$ pulse to $-20 \mathrm{mV}$ from a holding potential of $-90 \mathrm{mV}$ (repetition interval $20 \mathrm{~s}$ ). $\mathrm{Na}_{\mathrm{V}} 1.8$ currents were elicited by a $50 \mathrm{~ms}$ pulse to $+10 \mathrm{mV}$ from a holding potential of $-90 \mathrm{mV}$ (repetition interval $20 \mathrm{~s}$ ) in the presence of TTX $(1 \mu \mathrm{M})$, which fully inhibits TTX-sensitive channels but not $\mathrm{Na}_{\mathrm{V}} 1.8$ at this concentration. Recordings were taken at ambient room temperature $\left(22^{\circ} \mathrm{C}\right)$ after $5 \mathrm{~min}$ incubation of each concentration. Peak current post-SxIIIC addition (I) was normalised to buffer control $\left(\mathrm{I}_{0}\right)$. $\mathrm{IC}_{50}$ s were determined by plotting difference in peak current $\left(\mathrm{I} / \mathrm{I}_{0}\right)$ and $\log$ peptide concentration. Concentration-response curves were fitted using the log (inhibitor) vs. response-variable slope (four parameters) Equation (1).

$$
\mathrm{y}=1 /\left(1+10^{\wedge}\left(\left(\log \mathrm{IC}_{50}-\mathrm{x}\right) \times \text { HillSlope }\right)\right)
$$


Calculated $\mathrm{IC}_{50}$ were compared across subtypes and statistical differences determined by ordinary one-way ANOVA.

Current-voltage (I-V) curves were generated from a holding potential of $-90 \mathrm{mV}$ using a series of $500 \mathrm{~ms}$ step pulses ranging from -100 to $+55 \mathrm{mV}$ in $5 \mathrm{mV}$ increments (repetition interval $5 \mathrm{~s}$ ). Conductance-voltage (G-V) curves were generated by calculating the conductance $(\mathrm{G})$ at each voltage (V) using the equation $G=I /(V-V r e v)$, where Vrev is the reversal potential, and were fitted with a Boltzmann Equation (2).

$$
\mathrm{y}=1 /\left(1+\mathrm{e}^{\wedge}\left(\left(\mathrm{V}_{50}-\mathrm{x}\right) / \text { Slope }\right)\right)
$$

Voltage dependence of steady-state fast inactivation was assessed using a $10 \mathrm{~ms}$ pulse of $-20 \mathrm{mV}$ immediately after the $500 \mathrm{~ms}$ step (described above) to assess the availability of non-inactivated channels. Off rate data were acquired as previously described [22]. Briefly, using a holding potential of $-90 \mathrm{mV}$ and a $50 \mathrm{~ms}$ pulse to $-20 \mathrm{mV}$ every $20 \mathrm{~s}(0.05 \mathrm{~Hz})$ peptides at $\mathrm{IC}_{90}$ concentration, SxIIIC $(1 \mu \mathrm{M})$ and KIIIA ( $3 \mu \mathrm{M}$; determined in previous studies [23]), were incubated for $3 \mathrm{~min}$ before step-wise wash out with extracellular solution every $3 \mathrm{~min}$ for $35 \mathrm{~min}$.

\subsection{NMR Experiments}

NMR experiments were carried out on a Bruker Avance III equipped with a cryoprobe (Bruker, Sydney, NSW, Australia). A sample of SxIIIC was dissolved in $90 \% \mathrm{H}_{2} \mathrm{O} / 10 \% \mathrm{D}_{2} \mathrm{O}(v / v)$ at $1 \mathrm{mg} / \mathrm{mL}$. All NMR experiments were conducted at $\mathrm{pH} 4.0$, and one-dimensional (1D) ${ }^{1} \mathrm{H}$ spectra, two-dimensional (2D) total correlated spectroscopy (TOCSY) and nuclear Overhauser effect spectroscopy (NOESY) experiments were run at $298 \mathrm{~K}$. In addition, experiments including ${ }^{1} \mathrm{H}-{ }^{15} \mathrm{~N}$ HSQC spectra and variable temperature 2D TOCSY $(283-303 \mathrm{~K})$ in $90 \% \mathrm{H}_{2} \mathrm{O} / 10 \% \mathrm{D}_{2} \mathrm{O}(v / v)$ and ${ }^{1} \mathrm{H}-{ }^{13} \mathrm{C}$ HSQC in $100 \% \mathrm{D}_{2} \mathrm{O}(v / v)$ at $298 \mathrm{~K}$ were also run.

\subsection{NMR Structure Calculations}

TopSpin 3.5 (Bruker, Sydney, NSW, Australia) was used to process all NMR spectra. Following the sequential assignment of SxIIIC using CCPNMR Analysis 2.4 [24], a list of inter-proton distances was generated. By comparing measured $\mathrm{H} \alpha$ chemical shifts to reported random coil $\mathrm{H} \alpha$ shifts [25], the secondary structure of SxIIIC was predicted. $\mathrm{H} \alpha, \mathrm{C} \alpha, \mathrm{C} \beta, \mathrm{HN}$ chemical shifts derived from TOCSY, NOESY, ${ }^{1} \mathrm{H}-{ }^{13} \mathrm{C}$ HSQC, and ${ }^{1} \mathrm{H}-{ }^{15} \mathrm{~N}$ HSQC spectra were used to calculate backbone $(\Phi$ and $\varphi$ ) dihedral angles constraints in TALOS-N [26]. Additional $\chi 1$ and $\chi 2$ side-chain dihedral angle restraints were derived using DISH [27]. Peak assignments were refined following several rounds using the ANNEAL function in CYANA v3.97 [28]. Additional H-bond restraints were included derived from temperature coefficient experiments in combination with $\mathrm{D}_{2} \mathrm{O}$ exchange data [29]. Finally, protocols in the RECOORD database were used in CNS to calculate 50 structures. These 50 structures were further refined in a water shell using CNS [30]. Based on lowest energy, fewest violations, and the best MolProbity scores [31], a final set of 20 structures were chosen to represent SxIIIC. The final 20 structure of SxIIIC have been deposited in the Protein Data Bank (PDB ID: 6X8R) as well as the Biological Magnetic Resonance Bank (BMRB ID: 30758).

\section{Results}

\subsection{Activity-Guided Isolation of SxIIIC from Conus striolatus}

Crude C. striolatus venom $(\sim 100 \mu \mathrm{g} / \mathrm{mL})$ was fractioned using a linear gradient routinely used in-house for fractionation of cone snail venom ( $1 \% \mathrm{~B} / \mathrm{min})$. Given the limited material available, a single round of activity-guided fractionation using a high-throughput fluorescence assay assessing inhibition of veratridine-induced responses in the neuroblastoma cell line SH-SY5Y, expressing subtypes $\mathrm{Na}_{\mathrm{V}} 1.2$, 1.3, and 1.7 [32], identified compound(s) eluting in the buffer front on a Vydac 218TP C18 column as the bioactive components (Figure 1a). These were further purified by size-exclusion chromatography (Figure 1b), yielding a single bioactive fraction that was dominated by a mass of $2434.78 \mathrm{Da}$ (Figure 1c). 
Sequence determination by Edman degradation identified this compound as a C-terminal amidated $\left(^{*}\right)$ novel $\mu$-conotoxin with the sequence RGCCNGRGGCSSRWCRDHARCC*. The active peptide contained a cysteine framework consistent with the M-superfamily of conotoxins and therefore termed SxIIIC using standard $\mu$-conotoxin nomenclature.

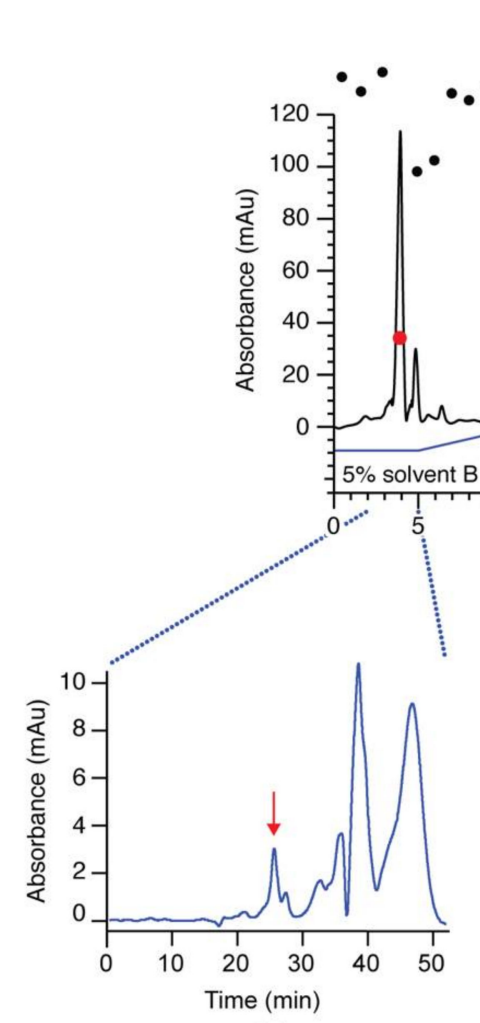

(b)

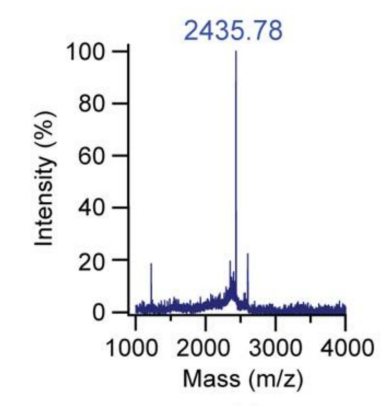

(c)

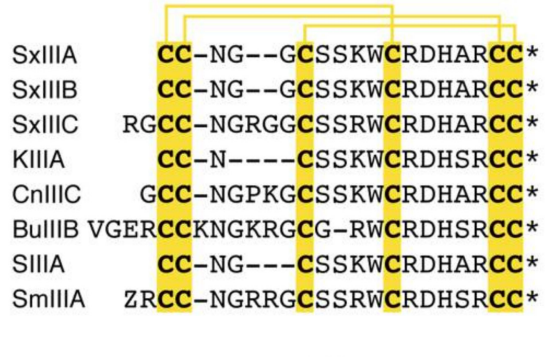

(d)

Figure 1. Activity-guided isolation of SxIIIC from C. striolatus venom. (a) Crude venom (200 $\mu \mathrm{g})$ isolated from one specimen of $C$. striolatus (inset) was fractionated and assayed for $\mathrm{Na}_{\mathrm{V}}$ inhibitor activity by fluorescence imaging in SH-SY5Y cells expressing subtypes $\mathrm{Na}_{V} 1.2,1.3$, and 1.7 (right $y$-axis; the activity of each fraction represented by circles overlaying the chromatogram). The bioactive component (red circle) eluted early. (b) Size-exclusion chromatography was used to further purify fractions collected between 2 and $5 \mathrm{~min}$ to isolate the bioactive component. The active fraction (red arrow) was dominated by (c) a mass of $2435.78 \mathrm{Da}(\mathrm{m} / \mathrm{z})$ and subjected to sequencing by Edman degradation, which identified a novel $\mu$-conotoxin with a C-terminal amidation named SxIIIC. (d) Sequence alignment of SxIIIC with previously reported $\mu$-conotoxins. * denotes $C$-terminal amidation.

\subsection{Peptide Synthesis of SxIIIC}

Due to the limited amount of native material available, disulfide connectivity was not determined experimentally. Upon comparison of SxIIIC to the sequences of previously reported $\mu$-conotoxins, SxIIIC was predicted to hold the canonical connectivity typically seen in the M-5 branch of the conotoxin M-superfamily of 1-4/2-5/3-6 [33]. Therefore, we produced synthetic SxIIIC with the disulfide connectivity of Cys3/Cys15, Cys4/Cys21, and Cys10/Cys22. SxIIIC was assembled using solid-phase peptide synthesis on rink amide-AM resin to produce C-terminal amidated peptide. Synthetic SxIIIC was thermodynamically oxidised and purified in high yield ( $80 \%$ based on pure linear starting material). Analytical RP-HPLC and ESI-MS were used to confirm crude linear and folded product (Figure 2a). While co-elution with native SxIIIC was not possible due to limited native material, the amide peaks of the 1D NMR spectrum (Figure 2b) are clearly distributed suggesting the peptide has a well-defined fold similar to previously described $\mu$-conotoxins. 


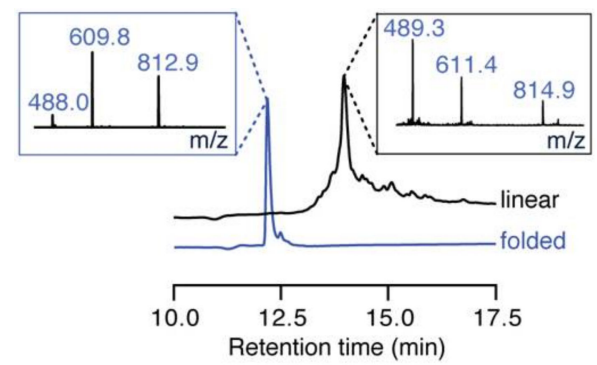

(a)

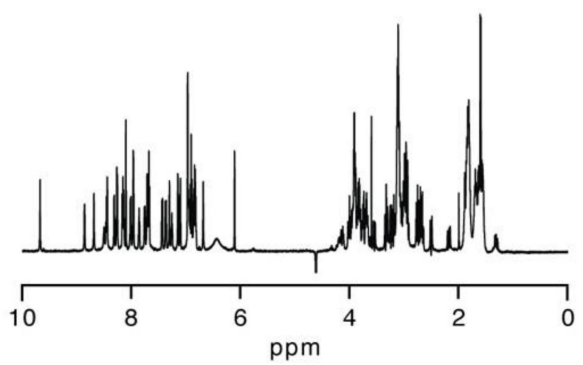

(b)

Figure 2. Peptide synthesis of SxIIIC. (a) RP-HPLC trace and ESI-MS spectra (insert) after cleavage (top) and oxidation (bottom) confirm successful synthesis and purification of SxIIIC. (b) $1 \mathrm{D}^{1} \mathrm{H}$ NMR spectrum of SxIIIC displays well-distributed amide peaks indicating a peptide with a definitive fold.

\subsection{SxIIIC Displays a Unique $\mathrm{Na}_{V}$ Channel Subtype Selectivity Profile}

We next evaluated the inhibition of synthetic SxIIIC of hNav channel subtypes by automated whole-cell patch-clamp electrophysiology in HEK293 cells expressing $\mathrm{hNa}_{\mathrm{V}} 1.1-1.7$ and $\mathrm{CHO}$ cells expressing hNa 1.8 . SxIIIC potently inhibited $\mathrm{hNa}_{\mathrm{V}} 1.4\left(\mathrm{IC}_{50} 15.11 \pm 10.7 \mathrm{nM}\right)$ and displayed ten-fold selectivity over subtypes $\mathrm{hNa}_{\mathrm{V}} 1.1,1.3,1.6$ and $1.7\left(\mathrm{IC}_{50} 132.0 \pm 11.6,89.4 \pm 11.1,124.9 \pm 11.1\right.$ and $152.2 \pm 21.8 \mathrm{nM}$, respectively) (Table 1 and Figure 3). Potent inhibition of $\mathrm{hNa}_{\mathrm{V}} 1.4$ is characteristic of most other $\mu$-conotoxins. Unexpectedly, we observed a significant loss $\left(<0.0001\right.$, one-way ANOVA) of activity against $h \mathrm{Na}_{\mathrm{V}} 1.2\left(\mathrm{IC}_{50} 363.8 \pm 53.8 \mathrm{nM}\right)$ compared to $\mathrm{hNa}_{\mathrm{V}}$ 1.4. SxIIIC did not affect the tetrodotoxin-resistant isoforms $\mathrm{hNa}_{\mathrm{V}} 1.5$ and $\mathrm{hNa} \mathrm{V}_{\mathrm{V}} 1.8$ when tested up to $1 \mu \mathrm{M}$, a trend consistent with other $\mu$-conotoxins [34-37]. Together these results indicate that SxIIIC displays a unique $\mu$-conotoxin selectivity profile of $\mathrm{hNa} \mathrm{V}_{\mathrm{V}} 1.4>\mathrm{hNa} \mathrm{V}_{\mathrm{V}} 1.3>\mathrm{hNa} \mathrm{V}_{\mathrm{V}} 1.1 \approx \mathrm{hNa} \mathrm{V}_{\mathrm{V}} 1.6$ $\approx \mathrm{hNa}_{\bigvee} 1.7>\mathrm{hNa}_{\mathrm{V}} 1.2>>\mathrm{hNa}_{\mathrm{V}} 1.5 \approx \mathrm{hNa}_{\mathrm{V}} 1.8$.

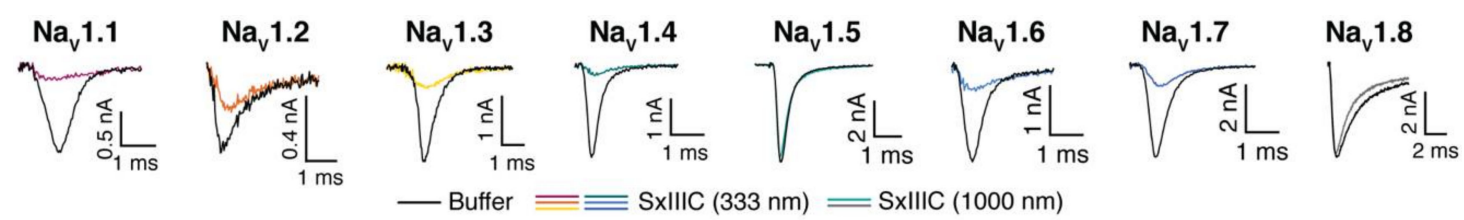

(a)

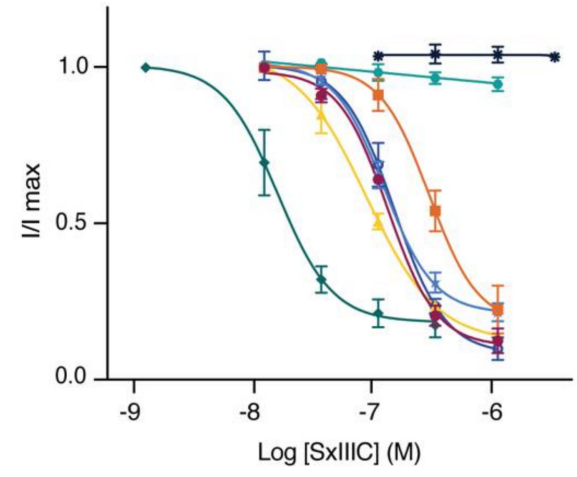

(b)

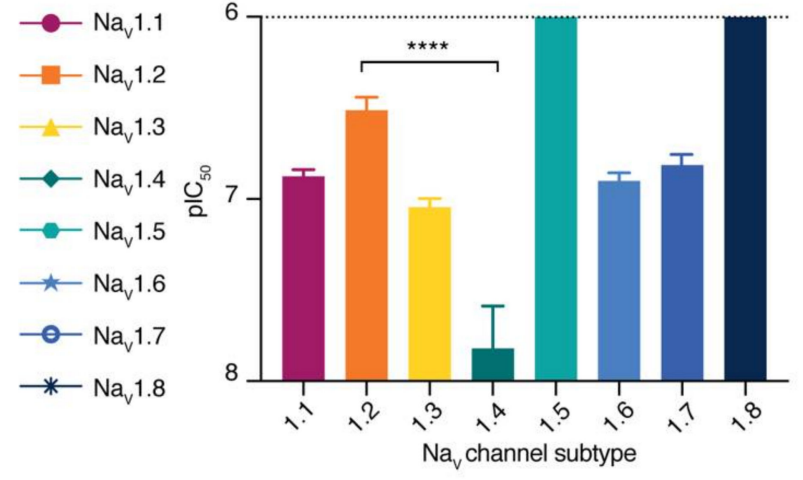

(c)

Figure 3. Activity of SxIIIC across $\mathrm{Na}_{\mathrm{V}}$ channel subtypes assessed by whole-cell patch-clamp electrophysiology. (a) Representative $\mathrm{hNa}_{\mathrm{V}} 1.1-1.8$ current traces before (black line) and after addition of SxIIIC (333 or $1000 \mathrm{nM}$; coloured line). Currents were obtained by a $50 \mathrm{~ms}$ pulse to $-20 \mathrm{mV}$ for $\mathrm{hNa}_{\mathrm{V}} 1.1-1.7$ and $+10 \mathrm{mV}$ for $\mathrm{hNa} \mathrm{V}_{\mathrm{V}} 1.8$. (b) Concentration-response curves and (c) comparative $\mathrm{IC}_{50}$ potency of SxIIIC at $\mathrm{hNa}_{\mathrm{V}} 1.1-1.8$. SxIIIC most potently inhibited $\mathrm{Na}_{\mathrm{V}} 1.4$, with 10-fold selectivity over $\mathrm{hNa}_{\mathrm{V}} 1.1,1.3,1.6$ and 1.7, 24-fold selectivity over $\mathrm{hNa}_{\mathrm{V}} 1.2{ }^{* * * *}, p$-value $\left.<0.0001\right)$ and $>100$-fold selectivity over $\mathrm{hNa}_{\mathrm{V}} 1.5$ and $\mathrm{hNa}_{\mathrm{V}} 1.8$. Data are presented as mean $\pm \mathrm{SEM}$, with $n=3-10$ cells per data point, see Table 1. 
Table 1. Potency of SxIIIC across $\mathrm{Na}_{\mathrm{V}}$ channel subtypes.

\begin{tabular}{ccc}
\hline Subtype & IC $_{\mathbf{5 0}} \pm$ SEM $(\mathbf{n M})$ & $\boldsymbol{n}$ \\
\hline $\mathrm{Na}_{V} 1.1$ & $132.0 \pm 11.6$ & 5 \\
$\mathrm{Na}_{V} 1.2$ & $363.8 \pm 53.8$ & 5 \\
$\mathrm{Na}_{V} 1.3$ & $89.4 \pm 11.1$ & 3 \\
$\mathrm{Na}_{V} 1.4$ & $15.11 \pm 10.7$ & 10 \\
$\mathrm{Na} 1.5$ & $>5000$ & 4 \\
$\mathrm{Na}_{V} 1.6$ & $124.9 \pm 11.1$ & 4 \\
$\mathrm{Na}_{V} 1.7$ & $152.2 \pm 21.8$ & 4 \\
$\mathrm{Na}_{V} 1.8$ & $>5000$ & 3 \\
\hline
\end{tabular}

\subsection{SxIIIC Is an Irreversible Presumptive Pore Blocker of $\mathrm{Na}_{V} 1.7$}

Additional experiments were conducted on $\mathrm{hNa}_{\mathrm{V}} 1.7$ to characterise the mechanism of action of SxIIIC. At hNav1.7, SxIIIC $(100 \mathrm{nM})$ elicited no change in channel voltage-dependence of fast inactivation $\left(\mathrm{V}_{50}\right.$ : control $-63.6 \pm 1.0 \mathrm{mV}$; SxIIIC $\left.-65.7 \pm 0.9 \mathrm{mV}\right)$ or activation $\left(\mathrm{V}_{50}\right.$ : control $-22.7 \pm 1.5 \mathrm{mV}$; SxIIIC $-24.7 \pm 1.9 \mathrm{mV}$ ), indicative of a pore blocker mechanism as observed for other $\mu$-conotoxins (Figure $4 \mathrm{a}, \mathrm{b})$. Interestingly, SxIIIC $(1 \mu \mathrm{M})$ irreversibly blocked current inhibition, as buffer washout over a $35 \mathrm{~min}$ time period was unable to recover any current (Figure $4 \mathrm{c}$ ). In contrast, inhibition by the nearly irreversibly KIIIA $(3 \mu \mathrm{M})$ could only be slowly reversed, with $\sim 30 \%$ of current recovered over the washout period, consistent with previous reports [38]. Notably, under these conditions, TTX inhibition is rapidly reversible without evidence of accumulation of inactivated channels [23].

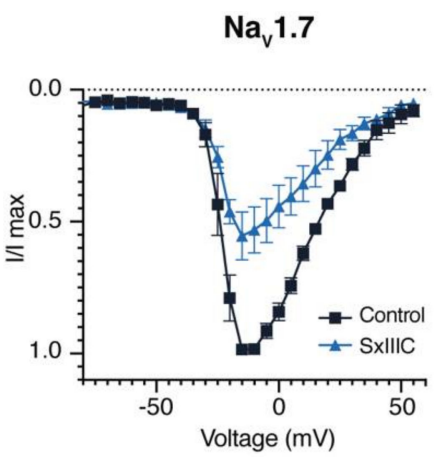

(a)

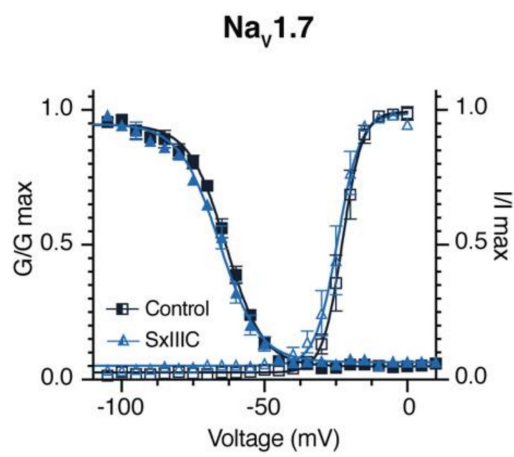

(b)

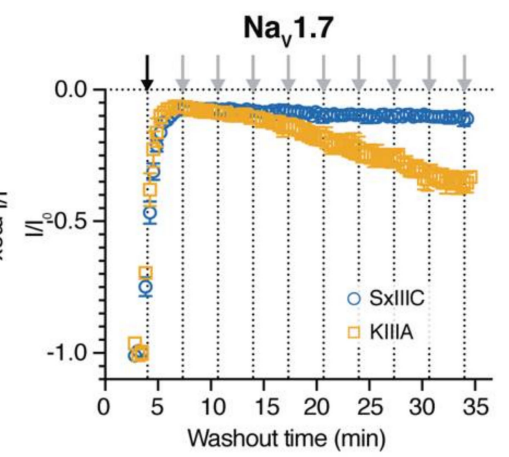

(c)

Figure 4. Effect of SxIIIC on the electrophysiological parameters of hNa 1.7 . (a) Voltage-current relationship curves before (black squares) and after addition of SxIIIC (blue triangles). SxIIIC (100 nM) inhibited peak current but did not affect the membrane voltage of peak current. (b) Conductance-voltage relationship before (black open squares) and after addition of SxIIIC (blue open triangles) and voltage-dependence of steady-state fast activation curves before (black squares), and after addition of SxIIIC (blue open triangles). SxIIIC (100 nM) did not shift the $\mathrm{V}_{1 / 2}$ of voltage-dependence of activation or $\mathrm{V}_{1 / 2}$ of steady-state fast inactivation at $\mathrm{hNa}_{\mathrm{V}}$ 1.7. (c) Wash out after addition of equipotent peptide ( $\left.\mathrm{IC}_{90}\right)$, SxIIIC ( $1 \mu \mathrm{M}$; blue circles) and KIIIA ( $3 \mu \mathrm{M}$; yellow squares). Black arrow indicates peptide addition and grey arrows indicate each subsequent wash out step. Current inhibition was irreversible for SxIIIC over $35 \mathrm{~min}$ and was almost irreversible for KIIIA. Data presented as mean \pm SEM, with $n=4$ cells per data point.

\subsection{NMR Solution Structure of SxIIIC}

2D TOCSY and NOESY NMR spectra were obtained and used for sequential assignment of individual amino acid spin systems. Secondary $\mathrm{H} \alpha$ chemical shifts were determined, and deviations from random coil $\mathrm{H} \alpha$ values were used to ascertain the presence of secondary structure within SxIIIC (Figure 5a) [25]. Consecutive negative deviations between Arg13 and His18 predicted an 
$\alpha$-helix in this region. The presence of medium-range NOEs supports the observation of secondary structure (Figure $5 b$ ).

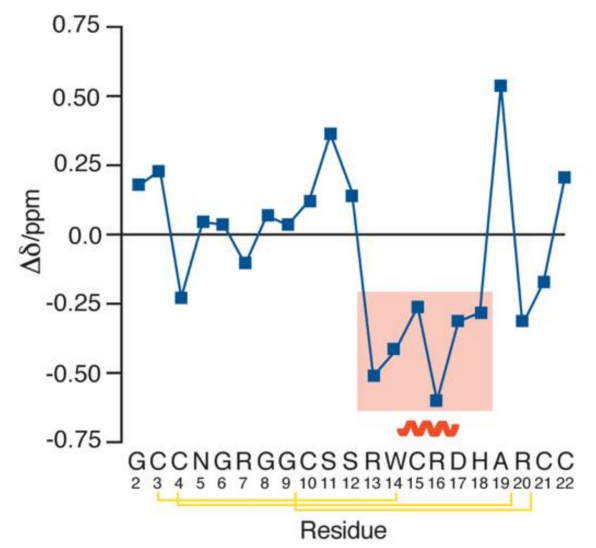

(a)

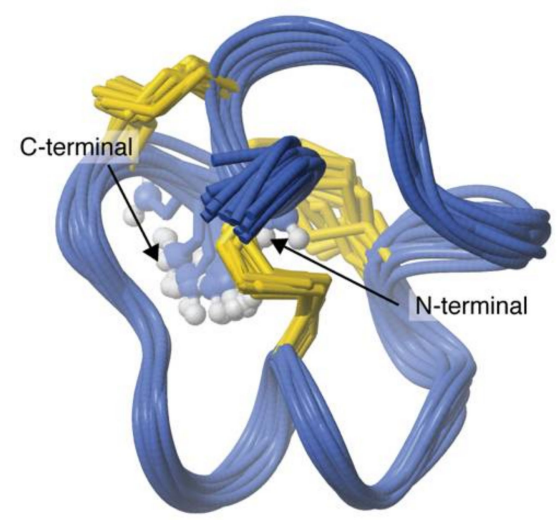

(c)

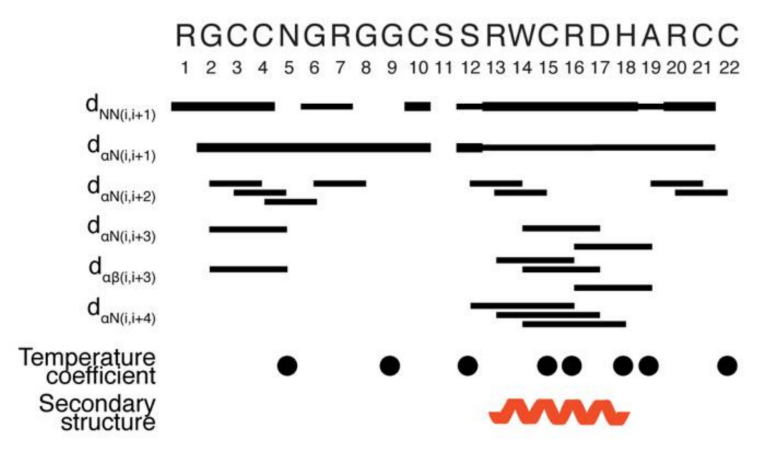

(b)

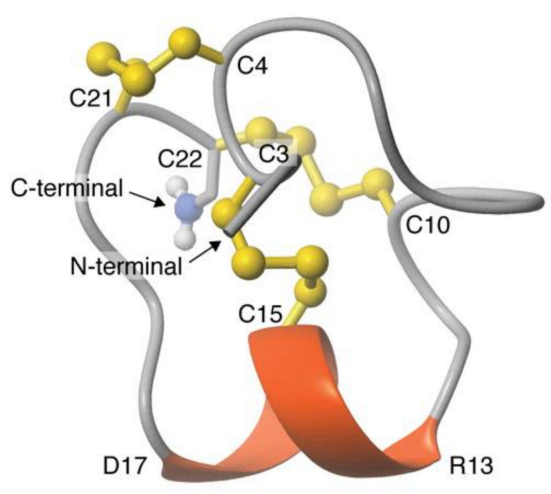

(d)

Figure 5. 3D NMR solution structure of SxIIIC. (a) Secondary H $\alpha$ chemical shift deviations from random coil values predicted the 3D structure to include an $\alpha$-helix between Arg13-His18 (shaded box). Disulfide connectivity indicated by yellow lines. (b) Summary of local and medium-range NMR data of SxIIIC. Bar width represents the strength of the NOE. Closed circles indicate residues involved in solvent protection as determined by temperature coefficient experiments. The $\alpha$-helix region is denoted by a curved line. (c) The 20 best conformations of NMR solution structure as analysed by MOLMOL superimposed across Cys3 and Cys22 [39]. (d) The final 3D structure of SxIIIC following CNS refinement in a watershell is composed of an $\alpha$-helix between residues Arg13-Asp17 (red helix) constrained by three disulfide bonds (yellow).

The three-dimensional (3D) NMR solution structure of SxIIIC was calculated using a simulated annealing protocol based on 173 NOE-derived distance restraints, and $12 \Phi$ and $10 \varphi$ dihedral restraints derived from TALOS-N (Table 2) [26]. $\chi 1$ and $\chi 2$ angle restraints were derived by DISH for Cys3, Cys4, Cys15, Cys21 ( $\chi 1)$, Cys4, and Cys15 ( $\chi 2$ ) [27]. Additional restraints included disulfide connectivities (Cys3/Cys15, Cys4/Cys21, and Cys10/Cys22) and hydrogen bonds determined through temperature coefficient and $\mathrm{D}_{2} \mathrm{O}$ exchange experiments (Arg16 $\rightarrow$ Ser12, Asp17 $\rightarrow$ Arg13, and His18 $\rightarrow$ Trp14). A total of 20 structures with no NOE violations $(>0.2 \AA)$ and no dihedral angle violations $(>2 \AA)$ were selected to represent based on the lowest total energy and MolProbity scores [31]. The final 20 structures were superimposed over backbone heavy atoms and the mean pairwise root-mean-square deviation (RMSD) was $0.76 \pm 0.17 \AA$ and $1.94 \pm 0.39 \AA$ for the all backbone and all heavy atom, respectively (Figure 5c). Energies and structural statistics for the NMR solution structure are shown in Table 2. The final structures were submitted to the Protein Data Bank (PDB ID: 6X8R) as well as the Biological Magnetic Resonance Bank (BMRB ID: 30758). 
Table 2. Statistical analysis of SxIIIC NMR solution structure.

\begin{tabular}{|c|c|}
\hline Distance Restraints & \\
\hline Intraresidue $(\mathrm{i}-\mathrm{j}=0)$ & 77 \\
\hline Sequential $(|\mathrm{i}-\mathrm{j}|=1)$ & 58 \\
\hline Medium range $(|i-j|<5)$ & 24 \\
\hline Long range $(|i-j|>5)$ & 7 \\
\hline Hydrogen bonds 1 & 6 \\
\hline Total & 172 \\
\hline \multicolumn{2}{|l|}{ Dihedral angle restraints } \\
\hline$\Phi$ & 12 \\
\hline$\Phi$ & 10 \\
\hline$\chi 1$ & 4 \\
\hline$x^{2}$ & 2 \\
\hline Total & 28 \\
\hline
\end{tabular}

\begin{tabular}{cc}
\hline Structure Statistics & \\
\hline Energies (kcal/mol, mean \pm SD) & $-465.4 \pm 17.8$ \\
Overall & $8.8 \pm 0.9$ \\
Bonds & $33.4 \pm 2.5$ \\
Angles & $16.2 \pm 2.8$ \\
Improper & $96.6 \pm 1.3$ \\
Dihedral & $-73.1 \pm 6.3$ \\
Van de Waals & $-547.7 \pm 19.5$ \\
Electrostatic & $0.1 \pm 0.0$ \\
NOE (exp.) & $0.1 \pm 0.1$ \\
Constrained dihedrals (exp.) & $0.76 \pm 0.17$ \\
Atomic RMSD (Å) & $1.94 \pm 0.39$ \\
Mean global backbone (1-22) & \\
Mean global heavy (1-22) & $14.8 \pm 6.6$ \\
MolProbity Statistics & $0.0 \pm 0.0$ \\
Clash score, all atoms ${ }^{2}$ & $0.0 \pm 0.0$ \\
Poor rotamers & $80.0 \pm 10.0$ \\
Ramachandran outliers (\%) & $2.4 \pm 0.3$ \\
Ramachandran favoured (\%) & $54.0 \pm 13.6$ \\
MolProbity score & \\
MolProbity percentile ${ }^{3}$ &
\end{tabular}

\begin{tabular}{cc}
\hline Violations & \\
\hline Distance constraints $(>0.2 \AA)$ & 0 \\
Dihedral-angle constraints $\left(>2^{\circ}\right)$ & 0
\end{tabular}

${ }^{1}$ Two hydrogen bond restraints included per bond. ${ }^{2}$ Number of steric overlaps $(>0.4 \AA) / 1000$ atoms. ${ }^{3} 100 \%$ is the best among structures of comparable resolution. $0 \%$ is the worst.

The NMR solution structure of SxIIIC is composed of a series of turns followed by a C-terminal $\alpha$-helix between residues Arg13 and Asp17 (Figure 5d). Medium-range NOEs (Figure 5b) and hydrogen bonds (Arg16 $\rightarrow$ Ser12, Asp17 $\rightarrow$ Arg13, and His18 $\rightarrow$ Trp14) support the observation of the $\alpha$-helix. SxIIIC is stabilised by three disulfide bonds with Cys3/Cys15 anchoring the N-terminal to the $\alpha$-helix.

\section{Discussion}

$\mathrm{Na}_{\mathrm{V}} 1.7$, along with $\mathrm{Na}_{\mathrm{V}} 1.1,1.3,1.6,1.8$, and 1.9 , plays an important role in pain signalling and has shown promise as a drug target for pain therapies. Toxins isolated from highly venomous creatures have evolved to potently and specifically target $\mathrm{Na}_{\mathrm{V}}$ channels and offer a great starting point as drug leads. However, a major limitation in their success has been the high sequence homology of the $\mathrm{Na}_{\mathrm{V}}$ channel pore, which could lead to undesirable side effects caused by off-target inhibition. As most toxins modulators that target the therapeutically relevant subtype $\mathrm{Na}_{\mathrm{V}} 1.7$ act as gating modifiers and 
bind to the voltage-sensing domain, they offer limited insights into the channel pore interactions. Despite $\mu$-conotoxins $\mathrm{Na}_{\mathrm{V}} 1.7$ pore blockers being less potent than gating modifiers, they may be used to further our understanding of potency and selectivity for $\mathrm{Na}_{\mathrm{V}}$ channel. In this body of work, we have isolated a novel $\mu$-conotoxin, SxIIIC, from C. striolatus, characterised the selectivity profile against $\mathrm{hNa}_{\mathrm{V}}$ channel subtypes and determined the NMR solution structure.

We first used activity-guided fractionation to isolate native SxIIIC from crude venom and subsequently determined the peptide sequence by Edman degradation. This sequence was identical to STRIO_41, recently reported from a C. striolatus transcriptome [40]. The unusual initial hydrophilic elution profile of native SxIIIC may be explained by the preparation of crude venom in 30\% acetonitrile which artificially attributed a higher gradient and may account for lack of identification in earlier proteomic studies [40]. When we synthetically produced SxIIIC the peptide eluted at $\sim 10 \%$ acetonitrile on a Gemini, $5 \mu \mathrm{m}$ C18 column. We next evaluated the pharmacological inhibition of hNa channel subtypes by automated whole-cell patch-clamp electrophysiology. SxIIIC displayed potent inhibition of $\mathrm{hNa}_{\mathrm{V}} 1.4\left(\mathrm{IC}_{50} 15.11 \pm 10.7 \mathrm{nM}\right)$ which is characteristic of most other $\mu$-conotoxins, and may provide an evolutionary advantage as $\mathrm{Na}_{V} 1.4$ is expressed exclusively in skeletal muscle and cone snail venom acts rapidly to immobilise prey [41,42]. Interestingly, when compared to hNav1.4, synthetic SxIIIC was significantly less potent against $\mathrm{hNa}_{V} 1.2\left(\mathrm{IC}_{50} 363.8 \pm 53.8 \mathrm{nM}\right)$. This was surprising as many other $\mu$-conotoxins preferentially target $\mathrm{Na}_{V} 1.4$ and $\mathrm{Na}_{V} 1.2$ [37], with the exception of BuIIIB which preferences $\mathrm{Na}_{\mathrm{V}}$ 1.3, as mentioned earlier [18]. However, many previous studies used rat and mouse isoforms as opposed to human, and species specificity may explain this variation. Another explanation may be the disulfide connectivity. Due to limited quantity of native material, we were unable to unambiguously determine disulfide connectivity. However, when we produced synthetic SxIIIC we observed a single major peak following thermodynamic oxidation of synthetic SxIIIC. Moreover, the biological activity of synthetic peptide at $\mathrm{Na}_{\mathrm{V}} 1.7$ is consistent with that of the native material, which inhibited $\mathrm{Na}_{\mathrm{V}} 1.7$ expressed in SH-SY5Y cells. Biological activity of the alternate folding arrangements remains to be determined.

Although SxIIIC was not selective for $\mathrm{hNa}_{\mathrm{V}} 1.7$, potent inhibition of this isoform is nonetheless unusual for the $\mu$-conotoxins. Only two $\mu$-conotoxins have reported nanomolar activity against $\mathrm{hNa}_{\mathrm{V}} 1.7$ isoforms: KIIIA and CnIIIC (485 nM) [20]. In 2011, McArthur et al. showed KIIIA inhibited $\mathrm{hNa}_{\mathrm{V}} 1.7$ with an $\mathrm{IC}_{50}$ of $147 \mathrm{nM}$ [19]. However, as these channel isoforms lacked $\beta$ subunits it is difficult to directly compare results. In our hands, in a comparable study by Tran et al. [23], KIIIA with native connectivity exhibited an $\mathrm{IC}_{50}$ of $363 \mathrm{nM}$ which is approximately two-fold less active than SxIIIC. At hNa 1.7 , the wash-off rate of SxIIIC was markedly slower than that of KIIIA assessed under identical experimental conditions. Notably, previous reports of a more readily reversible KIIIA [19] could be due to the step-wise, rather than continuous, solution exchange necessitated by using automated patch-clamp, and the relative lack of control of seal quality in these systems. In addition, the aforementioned co-expression with the $\beta 1$ subunit, as well as use of KIIIA isomer 1 with disulfide connectivity (Cys1/Cys15, Cys2/Cys9, and Cys4/Cys16) may contribute to these seemingly disparate results. However, given that TTX is readily reversible under the same conditions [23], and we do not observe any accumulation of inactivated channels with our pulse protocol, it is likely that a comparably slower off-rate of SxIIIC contributes to its greater potency at hNav1.7. Notably, the protocols used to compute $\mathrm{IC}_{50}$ values at each subtype do not directly permit calculation of on-rates, although these appeared comparatively slower at $\mathrm{Na}_{\mathrm{V}} 1.4$ and $\mathrm{Na}_{\mathrm{V}} 1.7$ (Supplementary Material, Figure S1). Furthermore, the relatively slow on-rate of SxIIIC resulted in steady-state inhibition only being achieved at higher concentrations. While this may be circumvented by substantially longer incubation times, this is difficult to achieve experimentally. As such, it is possible that our calculations are an under-estimate of the true $\mathrm{IC}_{50}$ values.

Given the high sequence homology between $\mu$-conotoxins (Figure 1d) and the highly conserved nature of $\mathrm{Na}_{\mathrm{V}}$ channel subtypes, particularly within the pore region, these findings may indicate subtle differences that could be exploited to further our understanding of potent $\mathrm{Na}_{\mathrm{V}} 1.7$ inhibition. Compared 
to KIIIA, the N-terminal tail of SxIIIC is extended by two residues, while the peptide sequence between the second and third cysteines (referred to as loop 1) is extended by four residues. It is possible that the extended loops of SxIIIC permit more interactions with $\mathrm{Na}_{\mathrm{V}}$ channels than KIIIA, and we thus sought to determine the NMR structure of SxIIIC by 2D homonuclear NMR for comparison to other $\mu$-conotoxins and to provide a foundation for future structure-activity relationship studies. SxIIIC structure is composed of a C-terminal $\alpha$-helix and is stabilised by three disulfide bonds. A marginally shorter $\alpha$-helix seen in the final structure compared to the earlier predicted structure is likely explained by additional restraints applied during refinement.

Recent landmark cryo-EM studies of $\mathrm{hNa}_{\mathrm{V}}$ channels provide insights into the molecular basis of $\mu$-conotoxin binding [14,43]. The calculated SxIIIC structure shared the characteristic $\alpha$-helix of other M-5 branch $\mu$-conotoxins KIIIA, BuIIIB, and SIIIA $[18,35,38]$. Residues extending from this helix have been shown to play an important role in $\mathrm{Na}_{\mathrm{V}}$ channel inhibition, including Lys7, Trp8, Arg10, Asp11, and His12 (KIIIA numbering) [38,44,45]. SxIIIC is almost identical to KIIIA in this region, with the exception of Arg13 (SxIIIC) which has a conservative substitution from Lys7 in KIIIA. However, this residue is either an Arg or Lys at this position in all other $\mu$-conotoxins and it is unsurprising that the cryo-EM structure has shown Lys7 in KIIIA to play an important role in channel binding, with the side chain extending down into the pore and acting to occlude the outer channel mouth [14]. It is likely that the analogous residue in SxIIIC similarly contributes to activity, although this remains to be experimentally confirmed. Compared to KIIIA, both the N-terminus and loop 1 of SxIIIC are extended. When SxIIIC is superimposed with the KIIIA/Na 1.2 structure (Supplementary Material, Figure S2), residues in loop 1 of SxIIIC appear to clash with the extracellular pore loop of domain I. As these are dynamic environments, it is likely that SxIIIC shifts from this proposed binding mode to a more energetically favourable position, and in doing so may contribute additional contacts to the channel that could contribute to its irreversible inhibition and increase in potency at $\mathrm{Na}_{\mathrm{V}} 1.7$ compared to KIIIA. Furthermore, the N-terminal extension has been shown to influence $\mu$-conotoxin selectivity for neuronal $\left(\mathrm{Na}_{V} 1.2\right)$ and skeletal subtypes $\left(\mathrm{Na}_{V} 1.4\right)$ and may have influenced the observation of decreased potency at $\mathrm{Na}_{\mathrm{V}} 1.2$ [46]. Interestingly, $\mu$-conotoxin SmIIIA, which shares 90\% sequence identity with SxIIIC (Figure 1d), has an extended N-terminal (Pyroglutamate1 and Gly2) and an additional charged residue in loop 1 compared to SxIIIC, but only weakly inhibits mammalian Nav1.7 $\left(\mathrm{IC}_{50} 1.3 \pm 0.23 \mu \mathrm{M}\right)$ [37]. Further investigation of the structure-activity relationships of these peptides may help us understand the role of these extensions in $\mathrm{Na}_{\mathrm{V}}$ channel inhibition and selectivity.

In conclusion, we discovered a novel $\mu$-conotoxin SxIIIC, produced the peptide synthetically and evaluated its pharmacological and structure characteristics. To date, SxIIIC is one of the most potent $\mu$-conotoxin $\mathrm{hNa}_{\mathrm{V}} 1.7$ inhibitors, acting as a presumptive pore blockers, and presents as a promising peptide for $\mathrm{Na}_{\mathrm{V}}$ channel inhibitor development.

Supplementary Materials: The following are available online at http://www.mdpi.com/2227-9059/8/10/391/s1, Figure S1: Activity of SxIIIC across $\mathrm{Na}_{\mathrm{V}}$ channel subtypes assessed by whole-cell patch-clamp electrophysiology, Figure S2: SxIIIC superimposed over the KIIIA/Na 1.2 structure.

Author Contributions: Conceptualization, I.V., R.J.L. and C.I.S.; investigation, K.L.M., H.N.T.T. and J.R.D.; formal analysis, K.L.M. and J.R.D.; writing-original draft preparation, K.L.M.; writing—review and editing, K.L.M., J.R.D., R.J.L., I.V. and C.I.S. All authors have read and agreed to the published version of the manuscript.

Funding: This work was supported by an Australian Research Council (ARC) Future Fellowship (FT160100055) awarded to C.I.S., an Australian National Health and Medical Research Council (NHMRC) Program Grant (APP1072112) and Principal Research Fellowship (APP1119056) awarded to R.J.L., an Australian National Health and Medical Research Council (NMHRC) Career Development Fellowship (APP1162503) awarded to I.V., and an Early Career Fellowship (APP1139961) awarded to J.R.D., K.L.M. and H.N.T.T were supported by Australian Government Research Training Program Scholarships.

Acknowledgments: We thank Quentin Kaas from the Institute for Molecular Bioscience at the University of Queensland for helpful assistance with DISH analysis.

Conflicts of Interest: The authors declare no conflict of interest. 


\section{References}

1. Armstrong, C.M. Ionic pores, gates, and gating currents. Q. Rev. Biophys. 1974, 7, 179-210. [CrossRef] [PubMed]

2. Catterall, W.A. Voltage-gated sodium channels at 60: Structure, function and pathophysiology. J. Physiol. 2012, 590, 2577-2589. [CrossRef] [PubMed]

3. Catterall, W.A.; Goldin, A.L.; Waxman, S.G. International Union of Pharmacology. XLVII. Nomenclature and structure-function relationships of voltage-gated sodium channels. Pharmacol. Rev. 2005, 57, 397-409. [CrossRef] [PubMed]

4. Catterall, W.A.; Kalume, F.; Oakley, J.C. Nav1.1 channels and epilepsy. J. Physiol. 2010, 588, $1849-1859$. [CrossRef] [PubMed]

5. Lossin, C.; Nam, T.S.; Shahangian, S.; Rogawski, M.A.; Choi, S.Y.; Kim, M.K.; Sunwoo, I.N. Altered fast and slow inactivation of the $\mathrm{N} 440 \mathrm{~K} \mathrm{Na} 1.4$ mutant in a periodic paralysis syndrome. Neurology 2012, 79, 1033-1040. [CrossRef]

6. Tan, H.L.; Bink-Boelkens, M.T.; Bezzina, C.R.; Viswanathan, P.C.; Beaufort-Krol, G.C.; van Tintelen, P.J.; van den Berg, M.P.; Wilde, A.A.; Balser, J.R. A sodium-channel mutation causes isolated cardiac conduction disease. Nature 2001, 409, 1043-1047. [CrossRef]

7. Dib-Hajj, S.D.; Yang, Y.; Black, J.A.; Waxman, S.G. The Nav1.7 sodium channel: From molecule to man. Nat. Rev. Neurosci. 2013, 14, 49-62. [CrossRef]

8. Dib-Hajj, S.D.; Waxman, S.G. Sodium channels in human pain disorders: Genetics and pharmacogenomics. Annu. Rev. Neurosci. 2019, 42, 87-106. [CrossRef]

9. Vetter, I.; Deuis, J.R.; Mueller, A.; Israel, M.R.; Starobova, H.; Zhang, A.; Rash, L.D.; Mobli, M. Nav1.7 as a pain target-From gene to pharmacology. Pharmacol. Ther. 2017, 172, 73-100. [CrossRef]

10. Gilchrist, J.; Bosmans, F. Animal toxins can alter the function of Nav1.8 and Nav1.9. Toxins 2012, 4, 620-632. [CrossRef]

11. Tikhonov, D.B.; Zhorov, B.S. Predicting structural details of the sodium channel pore basing on animal toxin studies. Front. Pharmacol. 2018, 9, 880-894. [CrossRef] [PubMed]

12. Terlau, H.; Olivera, B.M. Conus venoms: A rich source of novel ion channel-targeted peptides. Physiol. Rev. 2004, 84, 41-68. [CrossRef] [PubMed]

13. Li, R.A.; Ennis, I.L.; French, R.J.; Dudley, S.C.; Tomaselli, G.F., Jr.; Marban, E. Clockwise domain arrangement of the sodium channel revealed by $\mu$-conotoxin (GIIIA) docking orientation. J. Biol. Chem. 2001, 276, 11072-11077. [CrossRef] [PubMed]

14. Pan, X.; Li, Z.; Huang, X.; Huang, G.; Gao, S.; Shen, H.; Liu, L.; Lei, J.; Yan, N. Molecular basis for pore blockade of human $\mathrm{Na}^{+}$channel $\mathrm{Na}_{\mathrm{V}} 1.2$ by the $\mu$-conotoxin KIIIA. Science 2019, 363, 1309-1313. [CrossRef] [PubMed]

15. Erak, M.; Bellmann-Sickert, K.; Els-Heindl, S.; Beck-Sickinger, A.G. Peptide chemistry toolbox-Transforming natural peptides into peptide therapeutics. Bioorg. Med. Chem. 2018, 26, 2759-2765. [CrossRef]

16. Tikhonov, D.B.; Bruhova, I.; Zhorov, B.S. Atomic determinants of state-dependent block of sodium channels by charged local anesthetics and benzocaine. FEBS Lett. 2006, 580, 6027-6032. [CrossRef]

17. Tosti, E.; Boni, R.; Gallo, A. $\mu$-Conotoxins modulating sodium currents in pain perception and transmission: A therapeutic potential. Mar. Drugs. 2017, 15, 295. [CrossRef]

18. Kuang, Z.; Zhang, M.M.; Gupta, K.; Gajewiak, J.; Gulyas, J.; Balaram, P.; Rivier, J.E.; Olivera, B.M.; Yoshikami, D.; Bulaj, G.; et al. Mammalian neuronal sodium channel blocker $\mu$-conotoxin BuIIIB has a structured N-terminus that influences potency. ACS Chem. Biol. 2013, 8, 1344-1351. [CrossRef]

19. McArthur, J.R.; Singh, G.; McMaster, D.; Winkfein, R.; Tieleman, D.P.; French, R.J. Interactions of key charged residues contributing to selective block of neuronal sodium channels by $\mu$-conotoxin KIIIA. Mol. Pharmacol. 2011, 80, 573-584. [CrossRef]

20. Markgraf, R.; Leipold, E.; Schirmeyer, J.; Paolini-Bertrand, M.; Hartley, O.; Heinemann, S.H. Mechanism and molecular basis for the sodium channel subtype specificity of micro-conopeptide CnIIIC. Br. J. Pharmacol. 2012, 167, 576-586. [CrossRef]

21. Walewska, A.; Skalicky, J.J.; Davis, D.R.; Zhang, M.M.; Lopez-Vera, E.; Watkins, M.; Han, T.S.; Yoshikami, D.; Olivera, B.M.; Bulaj, G. NMR-based mapping of disulfide bridges in cysteine-rich peptides: Application to the $\mu$-conotoxin SxIIIA. J. Am. Chem. Soc. 2008, 130, 14280-14286. [CrossRef] 
22. Vetter, I.; Lewis, R.J. Characterization of endogenous calcium responses in neuronal cell lines. Biochem. Pharmacol. 2010, 79, 908-920. [CrossRef]

23. Tran, H.N.T.; Tran, P.; Deuis, J.R.; Agwa, A.J.; Zhang, A.H.; Vetter, I.; Schroeder, C.I. Enzymatic ligation of a pore blocker toxin and a gating modifier toxin: Creating double-knotted peptides with improved sodium channel $\mathrm{Na}_{\mathrm{V}} 1.7$ inhibition. Bioconjug. Chem. 2020, 31, 64-73. [CrossRef]

24. Vranken, W.F.; Boucher, W.; Stevens, T.J.; Fogh, R.H.; Pajon, A.; Llinas, M.; Ulrich, E.L.; Markley, J.L.; Ionides, J.; Laue, E.D. The CCPN data model for NMR spectroscopy: Development of a software pipeline. Proteins 2005, 59, 687-696. [CrossRef] [PubMed]

25. Wishart, D.S.; Bigam, C.G.; Holm, A.; Hodges, R.S.; Sykes, B.D. ${ }^{1} \mathrm{H},{ }^{13} \mathrm{C}$ and ${ }^{15} \mathrm{~N}$ random coil NMR chemical shifts of the common amino acids. I. Investigations of nearest-neighbor effects. J. Biomol. NMR 1995, 5, 67-81. [CrossRef] [PubMed]

26. Shen, Y.; Bax, A. Protein backbone and sidechain torsion angles predicted from NMR chemical shifts using artificial neural networks. J. Biomol. NMR 2013, 56, 227-241. [CrossRef] [PubMed]

27. Armstrong, D.A.; Kaas, Q.; Rosengren, K.J. Prediction of disulfide dihedral angles using chemical shifts. Chem. Sci. 2018, 9, 6548-6556. [CrossRef] [PubMed]

28. Guntert, P.; Buchner, L. Combined automated NOE assignment and structure calculation with CYANA. J. Biomol. NMR 2015, 62, 453-471. [CrossRef] [PubMed]

29. Baxter, N.J.; Williamson, M.P. Temperature dependence of ${ }^{1} \mathrm{H}$ chemical shifts in proteins. J. Biomol. NMR 1997, 9, 359-369. [CrossRef]

30. Nederveen, A.J.; Doreleijers, J.F.; Vranken, W.; Miller, Z.; Spronk, C.A.; Nabuurs, S.B.; Guntert, P.; Livny, M.; Markley, J.L.; Nilges, M.; et al. RECOORD: A recalculated coordinate database of 500+ proteins from the PDB using restraints from the BioMagResBank. Proteins 2005, 59, 662-672. [CrossRef]

31. Williams, C.J.; Headd, J.J.; Moriarty, N.W.; Prisant, M.G.; Videau, L.L.; Deis, L.N.; Verma, V.; Keedy, D.A.; Hintze, B.J.; Chen, V.B.; et al. MolProbity: More and better reference data for improved all-atom structure validation. Protein Sci. 2018, 27, 293-315. [CrossRef] [PubMed]

32. Vetter, I. Development and optimization of FLIPR high throughput calcium assays for ion channels and GPCRs. Adv. Exp. Med. Biol. 2012, 740, 45-82. [PubMed]

33. Jacob, R.B.; McDougal, O.M. The M-superfamily of conotoxins: A review. Cell. Mol. Life. Sci. 2010, 67, 17-27. [CrossRef] [PubMed]

34. Lewis, R.J.; Schroeder, C.I.; Ekberg, J.; Nielsen, K.J.; Loughnan, M.; Thomas, L.; Adams, D.A.; Drinkwater, R.; Adams, D.J.; Alewood, P.F. Isolation and structure-activity of $\mu$-conotoxin TIIIA, a potent inhibitor of tetrodotoxin-sensitive voltage-gated sodium channels. Mol. Pharmacol. 2007, 71, 676-685. [CrossRef] [PubMed]

35. Schroeder, C.I.; Ekberg, J.; Nielsen, K.J.; Adams, D.; Loughnan, M.L.; Thomas, L.; Adams, D.J.; Alewood, P.F.; Lewis, R.J. Neuronally $\mu$-conotoxins from Conus striatus utilize an alpha-helical motif to target mammalian sodium channels. J. Biol. Chem. 2008, 283, 21621-21628. [CrossRef]

36. Leipold, E.; Markgraf, R.; Miloslavina, A.; Kijas, M.; Schirmeyer, J.; Imhof, D.; Heinemann, S.H. Molecular determinants for the subtype specificity of $\mu$-conotoxin SIIIA targeting neuronal voltage-gated sodium channels. Neuropharmacology 2011, 61, 105-111. [CrossRef]

37. Wilson, M.J.; Yoshikami, D.; Azam, L.; Gajewiak, J.; Olivera, B.M.; Bulaj, G.; Zhang, M.M. $\mu$-Conotoxins that differentially block sodium channels $\mathrm{Na}_{\mathrm{V}} 1.1$ through 1.8 identify those responsible for action potentials in sciatic nerve. Proc. Natl. Acad. Sci. USA 2011, 108, 10302-10307. [CrossRef]

38. Zhang, M.M.; Green, B.R.; Catlin, P.; Fiedler, B.; Azam, L.; Chadwick, A.; Terlau, H.; McArthur, J.R.; French, R.J.; Gulyas, J.; et al. Structure/function characterization of $\mu$-conotoxin KIIIA, an analgesic, nearly irreversible blocker of mammalian neuronal sodium channels. J. Biol. Chem. 2007, 282, 30699-30706. [CrossRef]

39. Koradi, R.; Billeter, M.; Wuthrich, K. MOLMOL: A program for display and analysis of macromolecular structures. J. Mol. Graph. 1996, 14, 51-55. [CrossRef]

40. Himaya, S.W.A.; Rai, S.K.; Pamfili, G.; Jin, A.-H.; Alewood, P.F.; Lewis, R.J. Venomic interrogation reveals the complexity of Conus striolatus venom. Aust. J. Chem. 2020, 73, 357-366. [CrossRef]

41. Olivera, B.M.; Seger, J.; Horvath, M.P.; Fedosov, A.E. Prey-capture strategies of fish-hunting cone snails: Behavior, neurobiology and evolution. Brain Behav. Evol. 2015, 86, 58-74. [CrossRef] [PubMed] 
42. Olivera, B.M.; Gray, W.R.; Zeikus, R.; McIntosh, J.M.; Varga, J.; Rivier, J.; de Santos, V.; Cruz, L.J. Peptide neurotoxins from fish-hunting cone snails. Science 1985, 230, 1338-1343. [CrossRef] [PubMed]

43. Shen, H.Z.; Liu, D.L.; Wu, K.; Lei, J.L.; Yan, N. Structures of human Na 1.7 channel in complex with auxiliary subunits and animal toxins. Science 2019, 363, 1303-1308. [CrossRef] [PubMed]

44. Khoo, K.K.; Feng, Z.P.; Smith, B.J.; Zhang, M.M.; Yoshikami, D.; Olivera, B.M.; Bulaj, G.; Norton, R.S. Structure of the analgesic $\mu$-conotoxin KIIIA and effects on the structure and function of disulfide deletion. Biochemistry 2009, 48, 1210-1219. [CrossRef]

45. Van Der Haegen, A.; Peigneur, S.; Tytgat, J. Importance of position 8 in $\mu$-conotoxin KIIIA for voltage-gated sodium channel selectivity. FEBS J. 2011, 278, 3408-3418. [CrossRef]

46. Schroeder, C.I.; Adams, D.; Thomas, L.; Alewood, P.F.; Lewis, R.J. N- and C-terminal extensions of $\mu$-conotoxins increase potency and selectivity for neuronal sodium channels. Biopolymers 2012, 98, 161-165. [CrossRef]

(C) 2020 by the authors. Licensee MDPI, Basel, Switzerland. This article is an open access article distributed under the terms and conditions of the Creative Commons Attribution (CC BY) license (http://creativecommons.org/licenses/by/4.0/). 